\title{
The Aliphatic Acylamide Amidohydrolase of Mycobacterium smegmatis: Its Inducible Nature and Relation to Acyl-Transfer to Hydroxylamine
}

\author{
By P. DRAPER \\ Department of Biochemistry, University College, London*
}

(Accepted for publication 16 August 1966)

\begin{abstract}
SUMMARY
Mycobacterium smegmatis NCTC 8159 grew well in a minimal medium with succinate or acetamide as sole carbon source. Washed bacteria or cell-free extracts hydrolyzed 15 monocarboxylic amides, but not 4 related $N$-substituted amides. Formamide was the best substrate, followed by $n$-butyramide. Extracts of bacteria grown on acetamide hydrolyzed formamide about 60 times and butyramide about 20 times as rapidly as bacteria grown on succinate. Other short-chain fatty acylamides were also more rapidly hydrolyzed, but benzamidase activity was not similarly induced by growth on acetamide. Extracts of bacteria grown on succinate transferred acyl groups from propionamide, butyramide and nicotinamide to hydroxylamine, to form hydroxamates. Transferase activity, unlike aliphatic amidase activity, was decreased in extracts of bacteria grown on acetamide. Amidase activity in extracts was purified twofold and freed from transferase activity. Formamidase and butyramidase activities were not separated, and were similarly affected by heat and dithio-bis-nitrobenzoic acid. The amidase was induced by growth on acetate and on butyramide, but not on propionate, butyrate or benzamide, all of which were good growth-substrates. $N$-methylacetamide and $N$-acetylacetamide were non-substrate inducers of amidase for bacteria growing on succinate.
\end{abstract}

\section{INTRODUCTION}

That mycobacteria are able to hydrolyze amides has been recognized by implication since Sauton (1912) described a chemically defined medium for Mycobacterium tuberculosis, which contained asparagine. Grossowicz \& Halpern $(1956 a, b, 1957)$ and Halpern \& Grossowicz (1957) found that bacteria and bacterial extracts from $M$. phlei and $M$. tuberculosis strain BCG hydrolyzed several amides, and they used inhibitors and heat-treatment to differentiate nicotinamidase, glycinamidase and asparaginase activities. Pershin \& Nesvab'da (1960) showed by heat-treatment that acetamidase and nicotinamidase were separate activities of a saprophytic mycobacterium. Kimura $(1959 a, b, c, d)$ studied $M$. avium and purified a nicotinamidase from it, as well as measuring the ability of $M$. avium, $M$. smegmatis and $M$. phlei to hydrolyze several amides, and to form hydroxamates from salts or amides of organic acids and hydroxylamine.

The characteristic patterns of amide-hydrolyzing activity were used by Bönicke

* Present address. National Institute for Medical Research, Mill Hill, London, N.W. 7. 
(1960) for classifying mycobacteria; the method has been discussed by Juhlin (1960) and Schneidau (1963), who also extended the range of amides used and included members of the genus Nocardia. Nagayama, Konno \& Oka (1961) and Urabe, Takei \& Saito (1965) investigated the formamide-hydrolysing ability of various mycobacteria, though they disagreed as to its usefulness in classification.

Bönicke (1960) found that acetamide was hydrolyzed by Mycobacterium smegmatis after incubation for $24 \mathrm{hr}$, but not in a shorter period. He attributed this to very slow hydrolysis, but the possibility of enzyme synthesis induced by acetamide was not specifically excluded. Several inducible enzymes have been found in mycobacteria: penicillinase (Bönicke \& Dittmar, 1957); enzymes for the oxidation of benzoic acids and catechol (Fitzgerald, Bernheim \& Fitzgerald, 1948; Gale, 1952); enzymes for the oxidation of inositol (Ottey \& Bernheim, 1956). Inducible permeases were found in M. smegmatis NCTC 8159 by Ellard \& Clarke (1959). The observation that increased oxygen uptake occurred only after a lag when acetamide was added to organisms of the same mycobacterium grown on succinate led to the discovery, described in this paper, that the hydrolysis of some amides by M. smegmatis NCTC 8159 is an adaptive process. A preliminary report has been presented (Draper, 1965).

\section{METHODS}

Organism. Mycobacterium smegmatis NCTC 8159 was obtained from the National Collection of Type Cultures, subcultured monthly on slopes of Lemco agar (Clarke \& Meadow, 1959) and stored at $4^{\circ}$.

Media. Bacteria for inoculation were grown overnight at $37^{\circ}$ with shaking in $5 \mathrm{ml}$ Lemco broth containing $0.05 \%$ Tween 80 . This culture was used to inoculate experimental media at the rate of $4 \mathrm{ml}$. inoculum/l. The experimental medium was based on the minimal medium of Kohn \& Harris (1941) without glucose, having trace-elements provided in $5 \mathrm{ml}$./l. of the solution described by Kelly \& Clarke (1962) and containing $0.05 \%$ Tween 80 . It was sterilized at $121^{\circ}$ for $15 \mathrm{~min}$. Solutions of carbon sources $(10 \%, w / v)$, sterilized separately at $115^{\circ}$ for $5 \mathrm{~min}$. or by filtration through Oxoid membranes, were added at the rate of $20 \mathrm{ml}$./1. The medium $(50 \mathrm{ml}$., $200 \mathrm{ml}$. or 11 .) was contained in conical flasks $(250 \mathrm{ml}$., 1 1., 51 . respectively). Cultures were incubated at $37^{\circ}$ with vigorous shaking for $40 \mathrm{hr}$.

Suspensions of bacteria and cell-free extracts. Mycobacterium smegmatis NCTC 8159 was collected by centrifugation, washed twice with $0.05 \mathrm{M}$-sodium potassium phosphate buffer ( $\mathrm{pH} 7.2$ ) containing $0.05 \%$ Tween 80 , and suspended in the same buffer. The dry weight was measured either by drying a known volume of bacteria washed with $0.05 \%$ Tween 80 , or by measuring the extinction of the suspension at $540 \mathrm{~m} \mu\left(E_{540}\right)$ and comparing it with that of suspensions of known dry weight. To prepare extracts the bacteria were washed twice with cold $0 \cdot 1 \mathrm{M}$-tris adjusted to $\mathrm{pH} 7 \cdot 2$ with concentrated $\mathrm{HCl}$ (tris buffer), suspended in the same buffer, and disrupted either by ultrasonic treatment in a $60 \mathrm{~W}$. ultrasonic device (M.S.E.) with a cooled cell containing $2 \mathrm{ml}$. suspension, or with a bacterial press modified from the apparatus described by Milner, Lawrence \& French (1950). The extract was centrifuged at 25,000 $\mathrm{g}$ for $20 \mathrm{~min}$. at $4^{\circ}$ to remove debris, and was stored at $-20^{\circ}$.

Further treatment of extracts. All these manipulations were carried out on ice-cooled solutions. Streptomycin sulphate was added to the extract $(1 \mathrm{~g} . / 40 \mathrm{ml}$.), and the pre- 
cipitated material, containing nucleic acids, was removed by centrifugation at $16,500 \mathrm{~g}$ for $20 \mathrm{~min}$. Solid ammonium sulphate was added to the clear supernatant fluid until it was $50 \%$ saturated; the precipitated material was collected after $15 \mathrm{~min}$. by centrifugation at $16,500 \mathrm{~g}$ for $20 \mathrm{~min}$. The sediment was carefully drained and dissolved in a small volume of tris buffer. The supernatant fluid was vacuum-dialyzed against tris buffer to remove $\left(\mathrm{NH}_{4}\right)_{2} \mathrm{SO}_{4}$ and streptomycin, and to concentrate the proteins.

The concentrated supernatant solution from $\left(\mathrm{NH}_{4}\right)_{2} \mathrm{SO}_{4}$ fractionation was further dialyzed against tris buffer containing $0.15 \mathrm{M}-\mathrm{KCl}$ and applied to a $40 \times 1.5 \mathrm{~cm}$. column of DEAE-Sephadex A-50. The column was eluted with 11 . tris buffer containing $\mathrm{KCl}$ in a linear concentration gradient from 0.15 to $0.45 \mathrm{M}$. The effluent was collected in $5 \mathrm{ml}$. fractions, and the extinction was measured at $280 \mathrm{~m} \mu$. Protein and amidase activity were also measured in the fractions. Fractions containing amidase activity were combined and vacuum-dialyzed, to give the material described below as partially purified enzyme.

Estimation of amide hydrolysis. The hydrolysis of amides was measured at $37^{\circ}$ in $0.05 \mathrm{M}$-phosphate buffer ( $\mathrm{pH} \mathrm{7.2)} \mathrm{for} \mathrm{organisms,} \mathrm{or} \mathrm{0.1} \mathrm{M-tris} \mathrm{buffer}(\mathrm{pH} \mathrm{7.2)} \mathrm{for} \mathrm{ex-}$ tracts. In the general method, samples $(1 \mathrm{ml}$.) of a mixture containing 0.04 or 0.02 $\mathrm{M}$-amide and organisms or extract were taken at appropriate times, and ammonia determined in Conway units (Conway, 1947) by the method described by Kelly \& Clarke (1962) but allowing diffusion of ammonia to occur for $90 \mathrm{~min}$. at $37^{\circ}$. Amounts of cells or protein were chosen to give measurable hydrolysis in $30 \mathrm{~min} .-1 \mathrm{hr}$; typically, $5 \mathrm{mg}$. adapted cells $(0.2 \mathrm{mg}$. for formamide) and $0.5 \mathrm{mg}$. protein were used in $10 \mathrm{ml}$. buffer. Of the amides used only formamide, pyruvamide and glutamine were significantly hydrolyzed by the alkali in the Conway units. Hydrolysis of formamide was alternatively followed by measuring the formamide remaining in the reaction mixture after incubation with extract, by using a modification of the hydroxamate reaction (Snell \& Snell, 1954). To $1 \mathrm{ml}$. of incubation mixture containing bacterial extract in

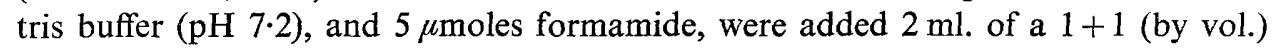
mixture of hydroxylamine hydrochloride $(15 \%, \mathrm{w} / \mathrm{v})$ and $\mathrm{NaOH}(15 \%$, w/v) cooled in ice. Amounts of protein used in the incubation mixture were adjusted to hydrolyze about half the formamide present in 5-10 min., and were typically 50-100 $\mu \mathrm{g} . / 5 \mathrm{ml}$. buffer. After $5 \mathrm{~min}$. or more (formation of the hydroxamate is very rapid, and it is stable under these conditions) at $37^{\circ}, 2 \mathrm{ml}$. of a solution of $\mathrm{FeCl}_{3}(5 \%$ (w/v) in 1.4 $\mathrm{N}-\mathrm{HCl}$ ) were added. The mixture was shaken vigorously for about $30 \mathrm{sec}$, and its extinction measured at $500 \mathrm{~m} \mu$. The colour faded, so that it was necessary to read at a fixed time after mixing, conveniently $1 \mathrm{~min}$. The colours were compared in each experiment with standards containing formamide but no enzyme. Phosphate interfered with the reaction.

Estimation of transferase activity. The ability of bacteria and extracts to transfer acyl groups from amides or fatty acid salts to hydroxylamine, to form hydroxamates, was measured as by Brammar \& Clarke (1964). Since the activity in Mycobacterium smegmatis was low, incubation times of up to $1 \mathrm{hr}$ were used, and corrections were made for the non-enzymic formation of hydroxamates which occurred in this time.

Heat and chemical denaturation. The enzyme preparation was heat-treated at $60^{\circ}$ for various periods in tris buffer $(\mathrm{pH} 7 \cdot 2)$. The mixture was cooled and used for amidase assay in the usual way. The thiol reagent dithio-bis-nitrobenzoic acid was used at $1.5 \times 10^{-6} \mathrm{M}$ in tris buffer ( $\mathrm{pH} 7 \cdot 2$ ) at $37^{\circ}$ or at $1.5 \times 10^{-5} \mathrm{M}$ in tris buffer $(\mathrm{pH} 8)$ con- 
taining $10^{-3} \mathrm{M}$-ethylene-diaminetetra-acetate, at room temperature (about $22^{\circ}$ ). The reaction with thiol groups was measured at $412 \mathrm{~m} \mu$, with cysteine as an internal standard. After use of the more concentrated reagent the enzyme was dialyzed against tris buffer ( $\mathrm{pH} \mathrm{7.2)} \mathrm{before} \mathrm{the} \mathrm{amidase} \mathrm{activity} \mathrm{was} \mathrm{measured.}$

Ultracentrifugal analysis. The partially purified enzyme preparation was concentrated by vacuum dialysis and further dialyzed against tris buffer containing $0 \cdot 2 \mathrm{M}-\mathrm{KCl}$. The non-diffusible material was clarified by centrifuging, and examined in a Spinco model $\mathrm{E}$ ultracentrifuge at $10^{\circ}$. Sedimentation coefficients were calculated from the observed rates of migration of protein boundaries.

Disc electrophoresis in acrylamide gel. Electrophoresis of extracts of bacteria and of the partially purified enzyme on columns of acrylamide gel was done by using the system of Ornstein (1964) and Davis (1964). Zones of protein were stained with $0 \cdot 1 \%$ naphthalene black in methanol + acetic acid + water $(4+16+1$, by vol. $)$, and the gels were de-stained electrolytically in the same solvent.

Protein estimation. Protein in extracts was measured by the modified Folin phenol method of Lowry, Rosebrough, Farr \& Randall (1951).

Chemicals. Pyruvamide was kindly prepared by Dr C. A. Vernon by the method of Claisen (Claisen \& Shadwell, 1878; Claisen \& Moritz, 1880) using acetyl cyanide (Tschelinzeff \& Schmidt, 1929). $\beta$-Hydroxypropionamide was made from $\beta$-propiolactone (Gresham et al. 1951), glycolamide from ethyl glycolate by ammoniolysis, and lactamide from lactide (Schmuck, 1924). Other chemicals were from commercial sources. Acetamide was recrystallized from acetone, sodium succinate from aqueous ethanol and tris from aqueous methanol.

\section{RESULTS}

\section{Hydrolysis of amides by washed bacteria}

Figure 1 shows typical curves of ammonia production from amides by washed Mycobacterium smegmatis grown on acetamide. Liberation of ammonia was linear with time during the period of measurement $(30 \mathrm{~min}$.). The rates at which washed

\section{Table 1. Rates of hydrolysis of aliphatic amides by washed Mycobacterium smegmatis NCTC 8159}

Carbon sources were present in the growth medium at $0.2 \%$. Amide hydrolysis was measured by following release of ammonia using Conway units (see Methods), and is expressed as $\mu$ moles $/ \mathrm{hr} / \mathrm{mg}$. dry weight. Figures in parentheses are numbers of experiments, and dashes that measurements were not made.

Growth substrate

$\begin{array}{llccccccc}\begin{array}{l}\text { Hydrolysis } \\ \text { substrate }\end{array} & \begin{array}{c}\text { Succi- } \\ \text { nate }\end{array} & \begin{array}{c}\text { Acetate } \\ \text { Propio- } \\ \text { nate }\end{array} & \begin{array}{c}\text { Buty- } \\ \text { rate }\end{array} & \begin{array}{c}\text { Acet- } \\ \text { amide }\end{array} & \begin{array}{c}\text { Butyr- } \\ \text { amide }\end{array} & \begin{array}{c}\text { Benz- } \\ \text { amide }\end{array} & \begin{array}{c}\text { Nicotin- } \\ \text { amide }\end{array} \\ \text { Formamide } & 13(2) & 741 & - & - & 803(4) & - & - & - \\ \text { Acetamide } & 0.7 & - & - & - & 9.2(6) & - & - & - \\ \text { Propionamide } & 0.7 & - & - & - & 13(2) & - & - & - \\ \text { Butyramide } & 1.7(9) & 11.8 & 2.6 & 1.9 & 26(11) & 4.8 * & 1.2 & 0.7 \dagger \\ \text { Valeramide } & 1.0 & - & - & - & 17(2) & - & - & -\end{array}$

* Butyramide added at $0.02 \%$ after $24 \mathrm{hr}$ growth on succinate gives 10 units. $\uparrow$ Nicotinamide supported growth very poorly. 
suspensions of bacteria grown on various carbon sources hydrolyzed aliphatic amides are shown in Table 1. Discrepancies up to twofold between rates of hydrolysis of a given amide in different preparations grown on the same carbon source were observed, but the relative rates were similar for each preparation. Formamide was the most rapidly hydrolyzed amide, followed in order by butyramide, valeramide, propionamide, acetamide.

Mycobacterium smegmatis grew equally well on succinate or acetamide as sole carbon source. Bacteria grown on acetamide hydrolyzed formamide 60 times and the other amides 13-19 times as rapidly as those grown on succinate. Bacteria grown on acetate as carbon source showed enhanced rates of amide hydrolysis, almost as great as acetamide-grown bacteria, but propionate and butyrate, though equally able to support growth, yielded bacteria with butyramidase activity only slightly greater than that obtained after growth on succinate. Butyramide, another good growth substrate, gave only slight enhancement, but was a more effective inducer when added after $24 \mathrm{hr}$ to bacteria growing on succinate. Benzamide was a good carbon source for growth, but induced no amidase activity; nicotinamide, a poor carbon source, was also inactive as an inducer.

Table 2. Hydrolysis of formamide and butyramide by cell-free extracts of Mycobacterium smegmatis NCTC 8159

Rates are given in $\mu$ moles of ammonia produced or of formamide destroyed $/ \mathrm{hr} / \mathrm{mg}$. protein. Range of results and number of experiments are given in parentheses.

Growth substrate

\begin{tabular}{rcc}
\cline { 2 - 2 } Amide & Succinate & Acetamide \\
Formamide & $188(82-460 ; 6)$ & $16980(3240-27000 ; 7)$ \\
Butyramide & $18(10-29 ; 6)$ & $210(73-343 ; 8)$
\end{tabular}

\section{Hydrolysis by cell-free extracts}

When a suspension of bacteria grown on acetamide was treated ultrasonically the rates of hydrolysis before and after breakage were, respectively ( $\mu$ moles $/ \mathrm{hr} / \mathrm{mg}$. dry weight organisms originally present) 29 and 26 for butyramide, and 1360 and 1700 for formamide. Centrifuged extracts of bacteria hydrolyzed amides at the rates shown in Table 2, where extracts from bacteria grown on succinate or acetamide are compared. Large variations occurred in the rates of amide hydrolysis among different preparations, especially those grown on acetamide, but the trend was clear. Formamide was hydrolyzed 90 times and butyramide 12 times as fast by extracts from bacteria grown on acetamide as by extracts from bacteria grown on succinate. The ratio of formamide hydrolysis to butryramide hydrolysis was $77 \pm 24$ S.D. ( 7 experiments) for extracts of acetamide-grown, and $11 \pm 6$ S.D. (5 experiments) for extracts of succinate-grown Mycobacterium smegmatis. The enzymic activity was slowly lost during storage of frozen extracts: in one sample it was decreased to $40 \%$ of the starting value after 3 months at $-10^{\circ}$. It was not protected by mercapto-ethanol $\left(10^{-4} \mathrm{M}\right)$.

\section{Hydrolytic activity for other amides}

Washed suspensions or cell-free extracts of Mycobacterium smegmatis also hydrolyzed benzamide, phenylacetamide, nicotinamide, malonamide, fumaramide, gluta- 
mine, asparagine. Of these, nicotinamide was the best substrate; it was hydrolyzed at about $20 \%$ of the rate for butyramide. Benzamide supported growth, but did not induce benzamidase or butyramidase activity when compared with succinate. In bacteria grown on acetamide the ability to hydrolyze benzamide was only about $20 \%$ of that of bacteria grown on succinate. Nicotinamide was a poor growth substrate and not an inducer of benzamidase (or butyramidase) activity.

\section{Effect of amides which were not growth-substrates}

The $N$-substituted amides $N$-methylformamide, $N$-methylacetamide, $N$-dimethylformamide and $N$-dimethylacetamide did not support growth of Mycobacterium

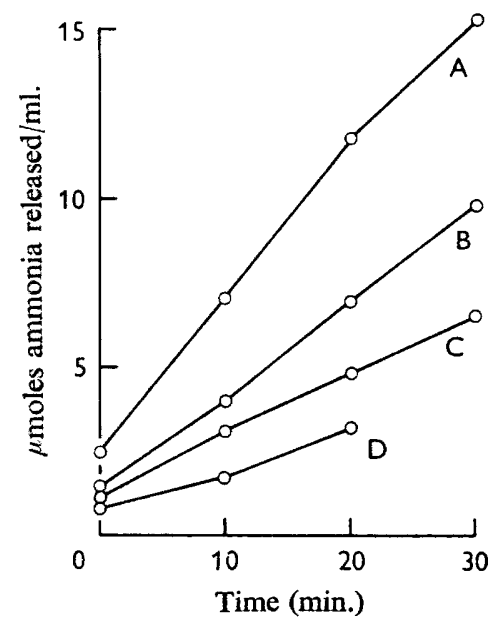

Fig. 1

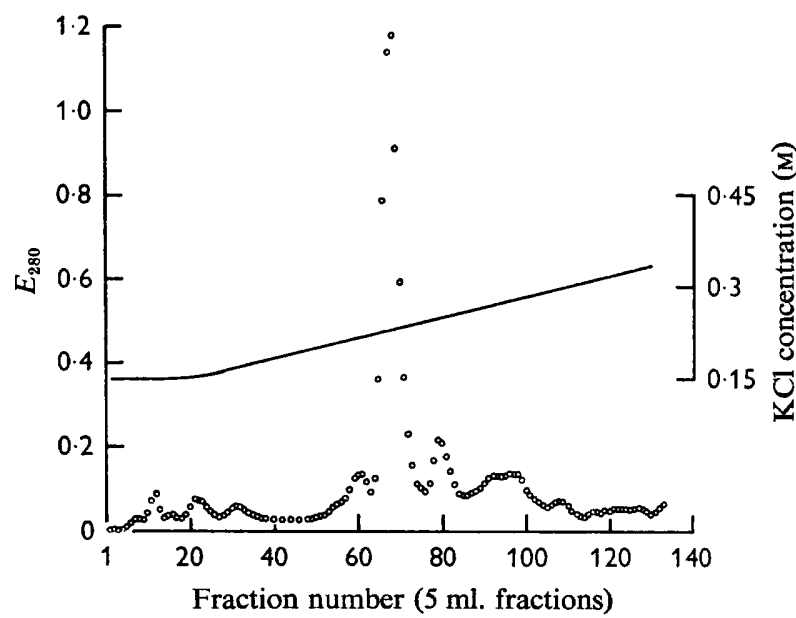

Fig. 2

Fig. 1. Rate of hydrolysis of amides by washed Mycobacterium smegmatis NCTC 8159 . The bacteria were grown on minimal medium + acetamide, and washed as described under Methods using $4.5 \mathrm{mg}$. of cells $/ 10 \mathrm{ml}$. buffer. Production of ammonia from amides $(0.02 \mathrm{M})$ was measured by using Conway units. Curve A, butyramide; B, valeramide; C, acetamide; $\mathrm{D}$, hexanoamide.

Fig. 2. Elution of protein from DEAE Sephadex column. Cell-free extract of Mycobacterium smegmatis NCTC 8159, grown on acetamide, was freed from nucleic acids with streptomycin. The material soluble in $50 \%$ saturated ammonium sulphate was applied to a column of DEAE Sephadex A 50 in $0.1 \mathrm{M}$-tris buffer (pH 7.2) containing $0.15 \mathrm{M}-\mathrm{KCl}$, and was eluted with a linear gradient $(0 \cdot 15-0.45 \mathrm{M}-\mathrm{KCl})$. Concentration was measured by conductivity; the protein spectrophotometrically at $280 \mathrm{~m} \mu$ in the eluate.

\section{Table 3. Non-substrate inducers of amidase activity in Mycobacterium smegmatis NCTC 8159}

Rates of amide hydrolysis by cell-free extracts of bacteria grown on minimal medium, containing the additions shown, are given relative to the rates for succinate-grown bacteria. Values for succinate-grown bacteria in $\mu \mathrm{moles} / \mathrm{hr} / \mathrm{mg}$. protein are given in parentheses. Rates for acetamide are given for comparison.

Growth medium

Succinate

Succinate + formamide

Succinate $+N$-acetylacetamide

Succinate $+N$-methylacetamide Acetamide
Activity measured

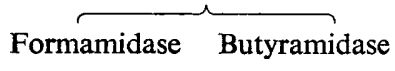$$
2 \cdot 1
$$ 
smegmatis; $N$-dimethylacetamide inhibited growth on succinate. None of these substances was hydrolyzed. Formamide was a substrate of the enzyme, but did not support growth. The effects of some of these compounds on the amidase activity of extracts of bacteria grown on succinate in their presence $(10 \mathrm{~mm})$ are shown in Table 3. The effect is also shown of $N$-acetylacetamide, which was extensively used by Brammar $\&$ Clarke (1964) as a non-substrate inducer of the amidase of Pseudomonas aeruginosa; the activities of extracts from bacteria grown on succinate alone or acetamide are included for comparison. Formamide (which presumably survived for only a short time in the medium) and $N$-methylacetamide caused a doubling in the formamidase activity but no change in the butyramidase activity. $N$-Acetylacetamide was a somewhat less effective inducer of both activities than acetamide.

\section{Partial purification of an amidase from Mycobacterium smegmatis}

An extract from Mycobacterium smegmatis grown on acetamide, having a specific activity of $3250 \mu \mathrm{moles} / \mathrm{hr} / \mathrm{mg}$. dry weight (formamidase) lost $10 \%$ of its activity after

\section{Table 4. Butyramidase, formamidase and protein content of fractions from DEAE-Sephadex column}

\begin{tabular}{|c|c|c|c|c|c|c|c|c|c|c|}
\hline raction number & 51 & 55 & 60 & 65 & 68 & 70 & 75 & 79 & 85 & 95 \\
\hline & 0.033 & 0.065 & $0 \cdot 141$ & $0 \cdot 360$ & $1 \cdot 18$ & 0.592 & $0 \cdot 102$ & $0 \cdot 215$ & 0.084 & $0 \cdot 130$ \\
\hline g. Protein/ml. & 10 & 20 & 40 & 120 & 410 & 210 & 32 & 60 & 27 & 35 \\
\hline $\begin{array}{l}\text { utyramidase } \\
(\mu \mathrm{mole} / \mathrm{hr} / \mathrm{mg} .)\end{array}$ & $<100^{*}$ & $<50^{*}$ & $<25^{*}$ & 507 & 507 & 486 & 138 & 20 & $<37^{*}$ & $<28^{*}$ \\
\hline $\begin{array}{l}\text { ormamidase } \\
\mu \mathrm{mole} / \mathrm{hr} / \mathrm{mg} \text {.) }\end{array}$ & 1800 & 500 & 1250 & $3.4 \times 10^{4}$ & $5.9 \times 10^{4}$ & $4 \times 10^{4}$ & $>8400$ & 2000 & 1700 & 450 \\
\hline
\end{tabular}

* Rate below sensitivity of assay. Maximum values calculated from known sensitivity.

streptomycin precipation. (Specific activity not determined since streptomycin interfered with the protein estimation.) After fractionation of nucleic acid-free material with $50 \%$ satd. $\left(\mathrm{NH}_{4}\right)_{2} \mathrm{SO}_{4}$ the insoluble material had a specific activity of 332 and the soluble protein of 7240 . The latter contained $62 \%$ of the original total activity, and the purification achieved in these two steps was $2 \cdot 2$. Butyramidase activity paralleled formamidase.

When the $50 \%$ satd. $\left(\mathrm{NH}_{4}\right)_{2} \mathrm{SO}_{4}$ soluble fraction was chromatographed on DEAESephadex, only one major peak of material absorbing at $280 \mathrm{~m} \mu$ was obtained (Fig. 2). Rates of hydrolysis of formamide and butyramide by some of the fractions, and the protein present in them, are shown in Table 4 . Both hydrolytic activities were associated with this major protein peak. The material in fractions 63-76 was collected and concentrated by ultrafiltration in vacuo, and constituted the partially purified extract referred to below. Recovery in the main protein peak of material added to the column was almost complete, and little apparent purification of the material was effected by its use. 


\section{Ultracentrifugal analysis of partially purified extract}

Two peaks were observed in the ultracentrifuge, which separated sufficiently well for the migration of each to be measured. The faster, which was considerably the larger, had a sedimentation coefficient of 8.3 and the slower of $4.2 \times 10^{-13} \mathrm{sec}$. Svedberg units (corrected for temperature and viscosity of $\mathrm{KCl}$ but not viscosity of tris buffer). There was no indication of any other component present in comparable amount.

\section{Disc electrophoresis}

The pattern of bands obtained by disc electrophoresis of the partially purified extract is shown in Fig. 3. For comparison are shown bands of the original extract after the removal of nucleic acids with streptomycin, and also bands of an extract from bacteria grown on succinate. The partially purified material contained only two major bands, and a trace of a third component. Of the major bands one was much larger than the other.

Table 5. Rates of hydrolysis of amides by partially-purified amidase preparation Mycobacterium smegmatis NCTC 8159

\begin{tabular}{|c|c|c|c|}
\hline & Rate & & Rate \\
\hline Formamide & $2.4 \times 10^{4}$ & Glycolamide & 232 \\
\hline Acetamide & 240 & Lactamide & 64 \\
\hline Propionamide & 302 & $\beta$-Hydroxypropionamide & 88 \\
\hline$n$-Butyramide & 613 & Pyruvamide & $5 \cdot 3^{*}$ \\
\hline$n$-Valeramide & 340 & Benzamide & $6 \cdot 7$ \\
\hline n-Hexanoamide & 140 & Phenylacetamide & 124 \\
\hline iso-Butyramide & 122 & Nicotinamide & $9 \cdot 0$ \\
\hline Acrylamide & 376 & $N$-Methylacetamide & $4 \cdot 3^{*}$ \\
\hline
\end{tabular}

\section{Substrate specificity of the partially purified material}

In Table 5 are shown the rates of hydrolysis of 16 amides by the partially purified enzyme. Apart from formamide, butyramide was the most rapidly hydrolyzed, and the rate decreased as the alkyl chain was lengthened or shortened, branched, or substituted by an hydroxyl group. Acrylamide was hydrolyzed more rapidly than its saturated analogue, propionamide. Pyruvamide was scarcely hydrolyzed.

The activity of the partially purified enzyme at various $p H$ values

The rates of hydrolysis of formamide and butyramide by the partially purified enzyme preparation in tris buffer at various $\mathrm{pH}$ values are shown in Fig. 4. The two activities followed similar curves. In phosphate buffer the rates were a little lower but the shapes of the curves remained the same.

\section{Inhibition of activity}

Taking the original rates of hydrolysis of formamide and butyramide by the partially purified enzyme as 100 , the rates after heating at $\mathrm{pH} 7.2$ at $60^{\circ}$ for various times 
were as follows: for $10 \mathrm{~min}$., 77 (formamide), 82 (butyramide); for $20 \mathrm{~min} ., 70$ and 78 ; for $30 \mathrm{~min}$., 58 and 68. Dithio-bis-nitrobenzoic acid had no effect in $60 \mathrm{~min}$. at $\mathrm{pH} 7 \cdot 2$, but when used at the higher concentration at $\mathrm{pH} 8$ for $24 \mathrm{hr}$ the hydrolysis of both substrates by the enzyme was decreased to $10 \%$ of its former value. However, the spectrophotometric assay showed that even after $24 \mathrm{hr}$ the reagent had reacted with not more than 1 mole of thiol in $10^{7} \mathrm{~g}$. enzyme-protein.

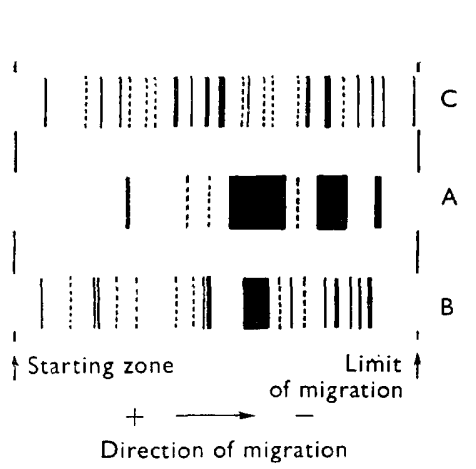

Fig. 3

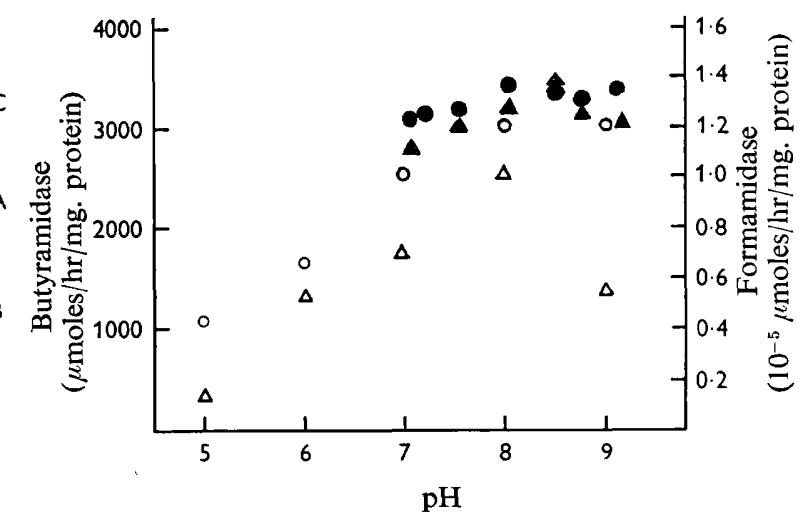

Fig. 4

Fig. 3. Disc electrophoresis of cell-free extracts of Mycobacterium smegmatis NCTC 8159 . Extracts were analysed on colums on acrylamide gel by using the system of Ornstein (1964) and Davis (1964); the bands were stained with naphthalene black. Pattern A, partiallypurified amidase from acetamide-grown bacteria; B, cell-free extract of acetamide-grown bacteria (nucleic acids removed with streptomycin); C, cell-free extract of succinate-grown bacteria. Approximately $50 \mu \mathrm{g}$. protein in pattern A, $25 \mu \mathrm{g}$. in patterns B and C.

Fig. 4. Variation of amidase activity with $\mathrm{pH}$ value. Rates were measured in $0.1 \mathrm{M}$-tris buffer or 0.05 M-phosphate buffer, as described in Methods. Ammonia release was followed in Conway units for butyramidase. The modified hydroxamate reaction was used to measure unhydrolyzed formamide for formamidase. Open symbols, phosphate buffer; solid symbols, tris buffer; $\triangle, \Delta$, butyramidase; $O, \bullet$, formamidase.

\section{Table 6. Rates of formation of hydroxamates from amides and hydroxylamine} by cell-free extracts of Mycobacterium smegmatis NCTC 8159

Rates are in $\mu$ moles hydroxamate formed $/ \mathrm{hr} / \mathrm{mg}$. protein. Figures in parentheses are rates of hydrolysis of amides in $\mu \mathrm{moles} / \mathrm{hr} / \mathrm{mg}$.

\begin{tabular}{|c|c|c|c|}
\hline \multirow[b]{2}{*}{ Amide } & \multicolumn{2}{|c|}{$\begin{array}{l}\text { Extracts from bacteria } \\
\text { grown on }\end{array}$} & \multirow{2}{*}{$\begin{array}{l}\text { Washed bacteria } \\
\text { grown on acetamide, } \\
\text { per mg. dry wt. }\end{array}$} \\
\hline & Acetamide & Succinate & \\
\hline Formamide & * & * & - \\
\hline Acetamide & $2 \cdot 6$ & - & $0.5(9.2)$ \\
\hline Propionamide & $11 \cdot 6$ & 25 & $1 \cdot 5(13)$ \\
\hline$n$-Butyramide & $2 \cdot 8(210)$ & $7 \cdot 7(18)$ & $0.6(26)$ \\
\hline$n$-Valeramide & 0.7 & - & - \\
\hline Benzamide & 0.9 & - & - \\
\hline Nicotinamide & 22 & 59 & - \\
\hline
\end{tabular}

\section{Transfer of acyl groups to hydroxylamine}

The rates of formation of acyl-hydroxamates from amides and hydroxylamine by cell-free extracts and suspensions of Mycobacterium smegmatis are shown in Table 6. 
Material from bacteria grown on acetamide catalyzed transfer only very slowly as compared with the rates of hydrolysis of amides; among $n$-alkanoamides the rate was maximal for propionamide rather than butyramide. Nicotinamide was a better substrate than propionamide. Higher rates were obtained with bacteria grown on succinate-the reverse of the situation for amide hydrolysis.

Formation of hydroxamates from salts of acids was slower still; from propionate it was 0.9 and $1.9 \mu \mathrm{moles} / \mathrm{hr} / \mathrm{mg}$. protein, respectively, for extracts from bacteria grown on acetamide or on succinate. Rates of hydrolysis of acylhydroxamates by extracts of acetamide-grown and succinate-grown bacteria were, respectively ( $\mu \mathrm{moles} / \mathrm{hr} / \mathrm{mg}$. protein); propionohydroxamate 0.6 and 1.9 ; butyrohydroxamate, 1.1 and 2.9 ; acetohydroxamate, not detectable.

An ammonium sulphate fraction (precipitated between 60 and $80 \%$ of saturation) containing most of the amidase activity of the original extract from acetamide-grown bacteria effected no transfer from butyramide or propionamide to hydroxylamine. The presence of transferase activity in other fractions was not investigated.

\section{DISCUSSION}

Apart from adding some more amides to the list of those known to be hydrolyzed by mycobacteria, the experiments reported here show that in Mycobacterium smegmatis NCTC 8159 several of these amidase activities are simultaneously induced by growth on acetamide as carbon source, and are much lower in bacteria grown on succinate. An inducible amidase rather than a permease is indicated since the increased activity is found with cell-free extracts as well as with whole organisms. There is some evidence that benzamidase activity varies according to growth conditions, independently of the aliphatic amidase. These findings bear on the use of amidase activities as a means of classifying species in the genus Mycobacterium. The presence or absence of an inducer in the growth medium will affect the observed amidase activity, while prolonged incubation of the bacteria with an inducer amide may change their hydrolytic activity from negative to positive for that amide. It is possible that differences in the inducing activity in the growth media used may account for the discrepancies between reports of formamidase activity in mycobacterium species (Nagayama et al. 1961; Urabe et al. 1965).

There are two possible explanations of the observed substrate specificity of the aliphatic amidase. Formamide may be hydrolyzed by a separate enzyme from the other aliphatic amides, or there may be a single enzyme with an anomalously high activity for formamide. The ratio uninduced:induced activity is much smaller for formamidase than for butyramidase in bacteria grown on acetate or acetamide, as compared with those grown on succinate. The difference is less marked when $N$-acetylacetamide is the inducer, while $N$-methylacetamide and formamide do not alter butyramidase activity but double formamidase activity. These facts might be explained either if the activities are separate but have common inducers or if they are activities of one enzyme, but a constitutive (in this system) butyramidase activity masks the small increase in the inducible enzyme caused by formamide or $N$-methylacetamide.

The two activities showed the same variation with $\mathrm{pH}$ value. Attempts to denature or to inhibit the activities selectively failed, and the attempted purification did not separate them. This last piece of evidence is compelling only if a substantial purification of the amidase was achieved, and the actual increase of specific activity obtained 
was only $2 \cdot 2$ times, suggesting that the purification was slight. However, both the electrophoretic and ultracentrifugal results showed that the partially purified amidase contained only two major components, although the crude cell-free extract contained many components. The possibility arises that the amidase in induced cells constitutes a major part of the protein extracted by the present method, and this is supported by the appearance of a very intense band of protein, migrating in the same position as one of the components of the partially-purified enzyme, in the disc electrophoresis pattern of the crude extract from induced cells. This band was absent in extract from succinategrown cells.

With other saprophytic mycobacteria Pershin \& Nesvab'da (1960) showed that the acetamidase differed from the nicotinamidase, and Nagayama et al. (1961) that the formamidase differed from the benzamidase; in both cases this was shown by differential heat-denaturation. The result of Nagayama et al. is confirmed by the present observation that benzamidase did not increase when formamide was induced.

It is interesting to compare the mycobacterial amidase with that isolated from Pseudomonas aeruginosa NCTC 8602 by Kelly \& Clarke (1962). The pseudomonad enzyme had a much sharper substrate specificity, and both crude extracts and a purified enzyme preparation hydrolyzed acetamide and propionamide, but scarcely at all formamide or butyramide. Neither enzyme hydrolyzed $N$-substituted amides. Both enzymes were induced by acetamide, $N$-methylacetamide and $N$-acetylacetamide (Kelly \& Clarke, 1962; Brammar \& Clarke, 1964), and also during growth on acetate (Kelly \& Kornberg, 1962a); in P. aeruginosa the kinetics of induction of amidase by acetate and acetamide differed markedly. The significance of this apparently useless induction of amidase by acetate is not understood, and it is of interest that it occurs in two unrelated species of bacteria, both of which are notable for their ability to grow on a wide variety of simple carbon compounds. W. J. Brammar (personal communication) has suggested that sufficient acetamide is formed chemically in a medium containing acetate and ammonia to induce the amidase in $P$. aeruginosa. Insufficient is known of the concentrations of acetamide needed to induce the mycobacterial amidase to decide the likelihood of this explanation.

Data reported here show that the adaptive amidase of Mycobacterium smegmatis NCTC 8159 is not responsible for the acyl transferase activity of crude extracts, since the activity disappeared from the ammonium sulphate fraction which contained the amidase (it was not sought in other fractions), while the rates of transfer were higher in succinate-grown bacteria than in acetamide-grown bacteria, which is the reverse of the situation with the formamidase. It is possible that the transferase is itself inducible: the conditions of its induction remain to be investigated. In Pseudomonas aeruginosa the enzyme appears to possess both activities (Brammar \& Clarke, 1963; Kelly \& Kornberg, 1962b), but in other mycobacteria transferase and amidase are separate. Kimura \& Sasakawa (1956) and Kimura (1959c) found that hydroxamate formation from fatty acids and their amides by Mycobacterium avium was not catalyzed by the corresponding amidase, while Grossowicz \& Halpern (1957) identified in $M$. phlei separate enzymes for transferring aspartyl residues from asparagine to hydroxylamine, for hydrolyzing asparagine and for hydrolyzing asparto-hydroxamate.

The author is grateful to Professor E. Baldwin for providing facilities in his department, to Mrs P. H. Clarke, Dr Pauline Meadow and many others for advice, sugges- 
tions and encouragement, and to Dr M. Rosemeyer for examining the partially purified material in the ultracentrifuge. The work was done during tenure of a LEPRA Fellowship in Biochemistry from the British Leprosy Relief Association, to whom the author is most grateful.

\section{REFERENCES}

BöNICKE, R. (1960). Uber das Vorkommen von Acylamidasen in Mycobacterien. IV. Die Differenzierung schnell wachsender Mycobacterien der Species Mycobacterium smegmatis, M. phlei, $M$. fortuitum, und $M$. thamnopheos durch Nachweis ihrer unterschiedlichen acylamidatischen Stoffwechselleistungen. Zentbl. Bakt. ParasitKde. Abt. 1. Originale 179, 209.

BönICKE, R. \& DITTMaR, W. (1957). Uber das Vorkommen von Cycloamidasen in Mycobacterien. Zentbl. Bakt. ParasitKde. Abt. 1. Originale 170, 366.

Brammar, W. J. \& Clarke, P. H. (1963). Induction and repression of an enzyme in Pseudomonas aeruginosa. J. gen. Microbiol. 32, iii.

Brammar, W. J. \& ClaRke, P. H. (1964). Induction and repression of Pseudomonas aeruginosa amidase. J. gen. Microbiol. 37, 307.

Claisen, L. \& Moritz, E. (1880). Über Propionylameisensäure. Ber. dt. chem. Ges. 13, 2121.

Claisen, L. \& Shadwell, J. (1878). Die Synthese der Brenztraubensäure. Ber. dt. chem. Ges. $11,1563$.

Clarke, P. H. \& MEadow, P. M. (1959). Evidence for the occurrence of permeases for tricarboxylic acid cycle intermediates in Pseudomonas aeruginosa. J. gen. Microbiol. 20, 144.

Conway, E. J. (1947). Micro-diffusion Analysis and Volumetric Error, revised edition. London: Crosby Lockwood and Sons Ltd.

Davis, B. J. (1964). Disc electrophoresis. II. Method and application to human serum proteins. Ann. N.Y. Acad. Sci. $121,404$.

DRAPER, P. (1965). The adaptive hydrolysis of amides by Mycobacterium smegmatis NCTC 8159 . J. gen. Microbiol. 39, viii.

EllaRD, G. A. \& ClaRke, P. H. (1959). Acetate and fumarate permeases of Mycobacterium smegmatis. J. gen. Microbiol. 21, 338.

Fitzgerald, R. J., BernheIm, F. \& FitzgrRald, D. B. (1948). The inhibition by streptomycin of adaptive enzyme formation in mycobacteria. J. biol. Chem. 175, 195.

Gale, G. R. (1952). The oxidation of benzoic acid by mycobacteria. 1. Metabolic pathways in $M$. tuberculosis, M. butyricum and $M$. phlei. J. Bact. 63, 273.

Gresham, T. L., Jansen, J. E., Shaver, F. W., Bankert, R. A. \& Fiedorek, F. T. (1951). $\beta$-Propiolactone. XI. Reactions with ammonia and amines. J. Am. chem. Soc. 73, 3168.

GrossowICZ, H. \& HALPERN, Y.S. (1956a). Inhibition of L-asparaginase in extracts of Mycobacterium phlei by D-asparagine. Nature, Lond. $177,623$.

Grossowicz, N. \& HALPERN, Y. S. (1956b). Inhibition of nicotinamidase activity in cell-free extracts of Mycobacterium phlei by 3-acetylpyridine. Biochim. biophys. Acta 20, 576.

GrossowicZ, N. \& HALPERN, Y. S. (1957). Enzymatic transfer and hydrolysis involving glutamine and asparagine. J. biol. Chem. $228,643$.

HalPERN, Y. S. \& Grossowicz, N. (1957). Hydrolysis of amides by extracts from mycobacteria. Biochem. J. 65, 716.

JURIIIN, I. (1960). Methods for the grouping and typing of mycobacteria. 3. Differentiation of anonymous mycobacteria into groups, sub-groups or types. Acta path. microbiol. scand. 50, 195.

Kelly, M. \& ClARKE, P. H. (1962). An inducible amidase produced by a strain of Pseudomonas aeruginosa. J. gen. Microbiol. 27, 305.

Kelly, M. \& Kornberg, H. L. (1962a). Discontinuity of amidase formation by Pseudomonas aeruginosa. Biochim. biophys. Acta 59, 517.

Kelly, M. \& Kornberg, H. L. (1962b). Amidase from Pseudomonas aeruginosa: a multi-headed enzyme. Biochim. biophys. Acta 64, 190.

Kelly, M. \& KoRnberg, H. L. (1964). Purification and properties of acyl-transferases from Pseudomonas aeruginosa. Biochem. J. 93, 557.

KIMURA, T. (1959a) Studies on metabolism of amides in mycobacteriaceae. I. Purification and properties of nicotinamidase from Mycobacterium avium. J. Biochem., Tokyo 46, 973.

KIMURA, T. (1959 b). Studies on metabolism of amides in mycobacteriaceae. II. Enzymatic transfer of nicotinyl group of nicotinamide to hydroxylamine in Mycobacterium avium. J. Biochem., Tokyo 46, 1133.

KIMURA, T. $(1959 c)$. Studies on metabolism of amides in mycobacteriaceae. III. Amidases and transferases in extracts from mycobacteriaceae. J. Biochem., Tokyo 46, 1271.

KIMURA, T. $(1959 d)$. Studies on metabolism of amides in mycobacteriaceae. IV. Formation and hydrolysis of hydroxamate. J. Biochem., Tokyo 46, 1399. 
Kimura, T. \& Sasakawa, T. (1956). Lipid metabolism of Mycobacterium tuberculosis avian. I. Enzymatic synthesis of hydroxamic acid from fatty acid and its specificity. J. Biochem., Tokyo 43, 175.

KoHN, H. I. \& HARRIS, J.S. (1941). On the mode of action of the sulphonamides. I. Action on Escherichia coli. J. Pharmac. exp. Ther. 73, 343.

Lowry, O. H., Rosebrough, N. J., FARR, A. L. \& Randall, R. J. (1951). Protein measurement with the Folin phenol reagent. J. biol. Chem. 193, 265.

Milner, H. W., Lawrence, N. S. \& French, C. S. (1950). Colloidal dispersion of chloroplast material. Science, N. Y. 111, 633.

NAGAYAMA, H., KonNo, K. \& OKA,S. (1961). Formamidase in mycobacteria and its use in differentiating saprophytic mycobacteria from other mycobacteria. Nature, Lond. 190, 1219.

OrNSTEIN, L. (1964). Disc electrophoresis. I. Background and theory. Ann. N. Y. Acad. Sci. 121, 321.

OTTEY, L. \& BERNHEIM, F. (1956). A comparison of the factors which effect the formation of adaptive enzymes for benzoic acid and inositol in a Mycobacterium. Enzymologia 17, 279.

Pershin, G. N. \& Nesvab'Da, V. V. (1960). A study of the amidase activity of bacteria and the effect on it of some chemotherapeutic substances. Biokhimiya (trans.), 20, 258.

Sauton, B. (1912). Sur la nutrition minérale du bacille tuberculeux. C. r. hebd. Séanc. Acad. Sci., Paris 155,860 .

Schmuck, A. (1924). Die Verkettungsreaktion der Amide von $\alpha$-Oxysäuren. Biochem. Z. 147, 193.

SCHNEIDAU, J.D. (1963). The amidase activity of certain species of Nocardia and Mycobacterium. Amer. Rev. resp. Dis. 88, 563.

Snell, F. P. \& SNell, C. T. (1954). Colorimetric Methods of Analysis, vol. Iv, p. 31. New York: Van Nostrand Co. Inc.

TschelinzeFF, W. \& SchMid, W. (1929). Uber ein neues Verfahren zur Darstellung von $\alpha$-Ketonsäuren. Ber. dt. chem. Ges. 62, 2210.

Urabe, K., TAKEI, N. \& SAITo, H. (1965). Formamidase activity of mycobacteria. I. Significance as a marker for differentiating mycobacteria. Am. Rev. resp. Dis. 91, 120. 